\title{
First find of Cadophora antarctica Rodr.-Andrade, Stchigel, Mac Cormack \& Cano in the Arctic
}

\author{
Vadim Alexandrovich Iliushin*
}

Botanical Institute of the Russian Academy of Sciences, Saint Petersburg, Russian Federation

\begin{abstract}
Cadophora antarctica Rodr.-Andrade, Stchigel, Mac Cormack \& Cano was isolated from spoil tip of coal mine in the Arctic, on the territory of the Svalbard archipelago, and is represented by strain IVA-206. Macro- and micromorphology of the isolate were examined along with partial sequences of Internal transcribed spacer rDNA region (ITS1-5.8S-ITS2) and D1/D2 region of 28S rDNA (LSU). The isolate C. antarctica IVA-206 had a number of features that distinguished it from the strain $C$. antarctica CBS 143035 from Antarctica. Colonies of Arctic strain had darker pigmentation, ramoconidia and conidia were larger, and the optimal growth temperature was higher. As a result of our study, we first discovered the microfungi $C$. antarctica Rodr.-Andrade, Stchigel, Mac Cormack \& Cano in the Arctic. Our study shows that $C$. antarctica Rodr.Andrade, Stchigel, Mac Cormack \& Cano is a bipolar species found in both the Arctic and Antarctic region.
\end{abstract}

Key words: microfungi, Svalbard, Arctic, Cadophora antarctica, bipolar species, spoil tips, coal mines

DOI: $10.5817 / \mathrm{CPR} 2020-2-11$

\section{Introduction}

The genus Cadophora was described in 1927 by Lagerberg and Melin with the type species $C$. fastigiata Lagerb. \& Melin, as a dark-colored hyphomycete that produce single phialides with distinct hyaline collarettes (Lagerberg et al. 1927). Conan transferred eight species of Cadophora to the genus Phialophora based on the similar morphology of phialide in 1937 (Conant 1937). Just recently, a change in the systematics of phialophora-like anamorphic spe- cies based on morphology was proposed by (Gams 2000). The change was confirmed by the data based on molecular studies later by Harrington and McNew (2003). It turned out that the genus Cadophora belongs to the order Helotiales (Leotiomycetes), and the genus Phialophora belongs to the order Chaetothryiales (Eurotiomycetes). To the date, according to the database Index Fungorum, the genus Cadophora had 22 species [1].

Received July 8, 2020, accepted December 21, 2020.

*Corresponding author: V. A. Iliushin<ilva94@yandex.ru>

Acknowledgements: This study was carried out as part of the state assignment according to the thematic plan of the Botanical Institute of the Russian Academy of Sciences (theme No. AAAA-A19-119020890079-6). The research was done using equipment of The Core Facilities Center "Cell and Molecular Technologies in Plant Science" at the Komarov Botanical Institute RAS (St.-Petersburg, Russia). 
Microfungi of the genus Cadophora are distributed worldwide and occupy various ecological niches. Most species of the genus Cadophora are plant parasites or endophytes (Walsh et al. 2018), wood destroyers (Travadon et al. 2015), and soil inhabitants (Domsch et al. 2007). Some species of the genus Cadophora are psychrotrophs. Thus, C. malorum, C. luteo-olivacea and C. fastigiata were found both in Antarctica (Blanchette et al. 2004, Arenz and Blanchette 2009) and in the Arctic (Kirtsideli et al. 2014, Bubnova and Nikitin 2017). However, these three species are cosmopolitan and distributed in different regions of the Earth (Lagerberg et al. 1927, Gams 2000, Harrington and McNew 2003, Domsch et al. 2007, Navarrete et al. 2011). Therefore, they are neither bipolar species with a separate distribution of the habitat zone in both polar zones (Wirtw et al. 2008), nor endemic species for regions of high latitudes.

In 2017, a new species Cadophora antarctica Rodr.-Andrade, Stchigel, Mac Cormack \& Cano (Crous et al. 2017) was described. The fungus was isolated from diesel-contaminated soils on the King George Island (Antarctica, South Shetlands archipelago, near to Carlini's Argentinean scientific base, $\left.62^{\circ} 14^{\prime} 17^{\prime \prime} \mathrm{S}, 58^{\circ} 40^{\prime} 02^{\prime \prime} \mathrm{W}\right)$.

\section{Material and Methods}

Samples were taken in August 2018 from spoil tip of coal mine No. 1-5 near the village of Barentsburg ( $78^{\circ} 03^{\prime} 51^{\prime \prime} \mathrm{N}$, $14^{\circ} 11^{\prime} 09^{\prime \prime}$ E), Svalbard archipelago. The spoil tip of coal mine from which sampling was carried out was at the formation stage (exploited).

The method of serial dilutions with spread on agar plates was used to isolate fungi cultures (Goldman and Green 2015). Single spore isolation was used to obtain pure culture. Inoculations were prepared from spore suspensions made in a $0.2 \%$ agar and $0.05 \%$ Tween 80 solution and
Until recently, there was no evidence of the discovery of this microfungi in other habitats.

It is generally accepted that the ecological similarity of the Polar Regions leads to the convergence of the mycobiota of the Arctic and Antarctic and a bipolar distribution of species (e.g. Ricklefs 2004). On the other hand, the vast distance separating the two polar regions limits the spread of microfungi and should minimize the number of identical species at the poles (Morlon et al. 2008). However, recent metagenomic studies have shown that Antarctic and Arctic soil micromycete communities show a high percentage of similarity (Cox et al. 2016). In polar regions, in contrast to the temperate and tropical ones, relatively small endemism and prevalence of fungi with widespread habitats are observed.

Thus, as a result of our study, we first discovered the microfungi Cadophora antarctica Rodr.-Andrade, Stchigel, Mac Cormack \& Cano in the Arctic, on the territory of the Svalbard archipelago. Arctic strain of this species was isolated from spoil tip of coal mine near Barentsburg. Also in this work, we have identified a number of features that distinguish the Arctic and Antarctic morphotypes.

agar plates were inoculated as described by Samson et al. (2014). The strain was designated as IVA-206.

The pure culture was grown on $\mathrm{CZ}$ medium without antibiotics at $20^{\circ} \mathrm{C}$ for 14 days for molecular analysis. DNA was extracted by using a DiamondDNA Plant kit (ABT, Russia, Barnaul) according to the manufacturer's instructions. Internal transcribed spacer rDNA region (ITS15.8S-ITS2) (White et al. 1990) and D1/D2 region of 28S rDNA (LSU) (O'Donnell, 1993) were used as a phylogenetic markers. Internal transcribed spacer rDNA region 
(ITS1-5.8S-ITS2) was amplified using the PCR-primers ITS1 (5'- TCC-GTA-GGTGAA-CCT-TGC-GG -3') and ITS4 (5'TCC-TCC-GCT-TAT-TGA-TAT-GC -3'). D1/D2 region of $28 \mathrm{~S}$ rDNA (LSU) was amplified using the PCR-primers NL-1 (5'GCATATCAATAAGCGGAGGAAAAG$\left.3^{\prime}\right)$ and NL-4 (5'- GGTCCGTGTTTCAA GACGG $\left.-3^{\prime}\right)$. At the end of amplification, the samples were detected by agarose gel electrophoretic method; sequencing of the obtained DNA fragments was carried out in the commercial organization BioBeagle (St. Petersburg) using the Sanger method. Sequences were proofread and edited using BioEdit version 7.1.9. Newly generated sequences were compared to the available sequences in the GenBank database (NCBI)

\section{Results and Discussion}

Our study of mycobiota of coal mine spoil tips in the Svalbard archipelago resulted in the isolation of strain IVA-206. BLAST analysis of the partial LSU gene sequence showed $100 \%$ similarity of the isolate IVA-206 (MT362720) and Cadophora antarctica CBS 143035 (= FMR 16056) (MG385663). BLAST analysis of the ITS region showed $99 \%$ similarity of the isolate IVA-206 (MN833351) and Cadophora antarctica CBS 143035 (=FMR 16056) (MG385664).

The observed micro- and macromorphology of isolate IVA-206 also corresponded to the micro- and macromorphology of Cadophora antarctica (Crous et al. 2017). Therefore, molecular and morphological data led to the conclusion that the obtained isolate IVA-206 belongs to the species Cadophora antarctica Rodr.Andrade, Stchigel, Mac Cormack \& Cano.

Micromorphology. Mycelium consists of hyaline to olive-brown, smooth to verrucous, thin- to thick-walled. Hyphae are anastomosing 2-4 $\mu \mathrm{m}$ wide. Conidiophores are mainly reduced to a short chain of ramoconidia on a scar, laterally or termi- by using BLAST instrument [2].

The isolate was cultivated on Czapek agar (CZ) (Raper and Thom 1949), malt extract agar (MEA) (Samson et al. 2010) for follow-up morphological observations. The isolate was inoculated on 11-cm Petri dishes and incubated for 21 days at 2, 4, $8,12,15,18,21,25,27$ and $30^{\circ} \mathrm{C}$. Color determination was performed according to the ISCC-NBS Centroid Color Charts (Kelly 1964), according to the recommendations of Nováková et al. (2012).

For micro-morphological examination, microscopy by Carl Zeiss AxioImager A1 was used.

Statistical processing (medium size) was performed using the statistical software package MS Excel 2007.

nally disposed on curved hyphae, simple, poorly developed, stalked, up to $200 \mu \mathrm{m}$ long, up to $4 \mu \mathrm{m}$ broad. Ramoconidia are brown or dark brown, sometimes irregularly colored, with one side darker than the opposite side, holoblastic, aseptate, in longitudinal chains to six, smooth- and thickwalled, ovoid-, cylindrical-, lemon-, flaskshaped, $6-16 \times 4-8 \mu \mathrm{m}$. Conidia are brown to dark brown, irregularly colored, holoblastic, aseptate, disposed in long, simple or branchy chains, smooth- and thickwalled, mostly broadly lens-shaped but irregularly due to one side being more oblate than the other side, $4-6 \times 4-8 \mu \mathrm{m}$.

The dimensional characteristics of the isolated strain IVA-206, in general, correspond to the description of Cadophora antarctica (Crous et al. 2017). The exceptions are sizes of ramoconidia and conidia. Ramoconidia and conidia of the strain isolated by us were, on average, 1.5 times larger than that of the Antarctic strain. In Cadophora antarctica from the Antarctic, the size of ramoconidia was $5-13 \times 2-4 \mu \mathrm{m}$ and the size of conidia was 4-5 × 3-4 $\mu \mathrm{m}$. Micromorphology is shown in Fig. 1c. 
Culture characteristics. Colonies cultivated on MEA after 14 days of cultivation at $21^{\circ} \mathrm{C}$ reached a diameter of 38 $-44 \mathrm{~mm}$, velvety, non-zonate, brownish black (\#28201c); exudates absent; sporulation abundant; reverse black (\#222222). Colonies on $\mathrm{CZ}$ after 14 days of cultivation at $21{ }^{\circ} \mathrm{C}$ reached a diameter of 34$37 \mathrm{~mm}$, velvety, non-zonate, brownish black (\#28201c); exudates absent; sporulation abundant; reverse black (\#222222). Cultivation at different temperature conditions did not affect the color and structure of the colonies. Colonies are shown in Fig. 1a, b.

The colonies of the strain IVA-206 on MEA were darker than the CBS 143035 strain from the Antarctic, and also did not have zonal coloration.

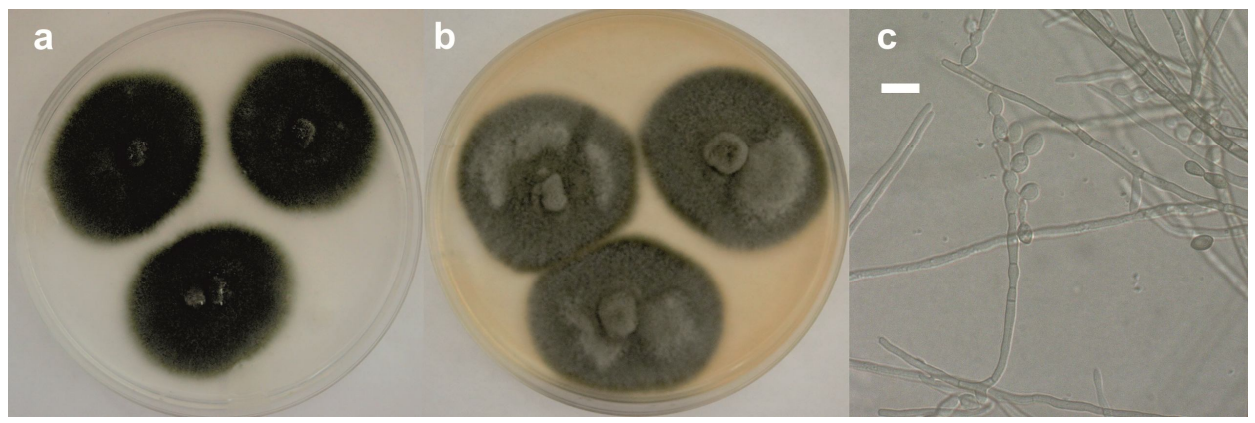

Fig. 1. Cadophora antarctica morphology in 14-day-old cultures: a - CZ, b - MEA, $\mathrm{c}-$ conidiophores and conidia. Scale bars $=10 \mu \mathrm{m}$.

The strain Cadophora antarctica IVA206 grows over a fairly wide temperature range $\left(\min .2^{\circ} \mathrm{C}, \max 27^{\circ} \mathrm{C}\right)$. This temperature range is not different from the range of the CBS 143035 strain from the Antarctic $\left(5-25^{\circ} \mathrm{C}\right)$. However, the Arctic and Antarctic strains differed quite strongly in the optimal growth temperature: $21^{\circ} \mathrm{C}$ and $15^{\circ} \mathrm{C}$, respectively.

The isolate Cadophora antarctica IVA206 that had been isolated from the spoil tip of coal mine of the Svalbard archipelago had a number of features that distinguished it from the strain Cadophora antarctica CBS 143035 from the South Shetland archipelago. IVA-206 colonies had darker pigmentation, ramoconidia and conidia were larger, and the optimal growth temperature was higher. It is likely that these differences in the phenotype are caused by milder environmental conditions for the Arctic strain, which is especially confirmed by a higher optimal growth temperature.

Thus, Cadophora antarctica Rodr.Andrade, Stchigel, Mac Cormack \& Cano is a bipolar species found in both the Arctic and Antarctic.

\section{References}

Arenz, B. E., Blanchette, R. A. (2009): Investigations of fungal diversity in wooden structures and soils at historic sites on the Antarctic Peninsula. Canadian Journal of Microbiology, 55: 46-56. https://doi.org/10.1139/W08-120

Blanchette, R. A., Held, B. W., Jurgens, J. A., McNew, D. L., Harrington, T. C., Duncan, S. M. and FARRELL, R. L. (2004): Wood-destroying soft rot fungi in the historic expedition huts of Antarctica. Applied and Environmental Microbiology, 70: 1328-1335. doi: 10.1128/aem.70.3. 1328-1335.2004 
Bubnova, E. N., Nikitin, D. A. (2017): Fungi in bottom sediments of the Barents and Kara seas. Russian Journal of Marine Biology, 43: 400-406. https://doi.org/10.1134/S1063074017050029

CONANT, N. F. (1937): The occurance of a human pathogenic fungus as a saprophyte in nature. Mycologia, 29: 597-598.

Cox, F., Newsham, K. K., Bol, R., Dungait, J.A. and Robinson, C. H. (2016): Not poles apart: Antarctic soil fungal communities show similarities to those of the distant Arctic. Ecology Letters, 19(5): 528-536. doi: 10.1111/ele.12587

Crous, P.W., [et al.] (2017): Fungal Planet description sheets: 625-715. Persoonia, 39: 270-467. doi: 10.3767/persoonia.2017.39.11

Domsch, K. H., Gams, W. and ANDERson, T.-H. (2007): Compendium of soil fungi. IHW-Verlag., Eching., $672 \mathrm{p}$.

GAMs, W. (2000): Phialophora and some similar morphologically little-differetiated anamorphs of divergent ascomycetes. Studies in Mycology, 45: 187-199.

Goldman., E., GreEn, L. H. (2015): Practical Handbook of Microbiology, $3^{\text {rd }}$ Edition. CRC Press, Boca Raton, USA, 1055 p.

Harrington, T. C., MCNew, D. L. (2003): Phylogenetic analysis places the Phialophora-like anamorph genus Cadophora in the Helotiales. Mycotaxon, 87: 141-151.

Kelly, K. L. (1964): Inter-Society Color Council - National Bureau of Standards Color Name Charts Illustrated with Centroid Color.Washington, DC: US Government Printing Office, 1964.

Kirtsideli, I. Y., Vlasov, D. Y., Barantsevich, E. P., Krylenkov, V. A. and Sokolov, V. T. (2014): Microfungi from soil of polar island Izvestia Tsik (Kara sea). Mikologiya I Fitopatologiya, 48(6): 365-371.

Lagerberg, T., Lundberg, G. and Melin, E. (1927): Biological and practical researches into blueing in pine and spruce. Svensk Skogsvårdsförening Tidskrift, 25: 145-272.

Morlon, H., Chuyong, G., Condit, R., Hubbell, S., Kenfack, D., Thomas, D., Valencia, R. and GREEN, J. L. (2008): A general framework for the distance-decay of similarity in ecological communities. Ecology Letters, 11(9): 904-917. doi: 10.1111/j.1461-0248.2008.01202.x

Navarrete, F., Abreo, E., Martínez, S.,, Bettucci, L. and Lupo, S. (2011): Pathogenicity and molecular detection of Uruguayan isolates of Greeneria uvicola and Cadophora luteo-olivacea associated with grapevine trunk diseases. Phytopathologia Mediterranea, 50(4): 166-175. doi: 10.14601/Phytopathol_Mediterr-9188

Nováková, A., Hubka, V., Saiz-Jimenez, C. and KolaŘík, M. (2012): Aspergillus baeticus sp. nov. and Aspergillus thesauricus sp. nov.: Two new species in section Usti originating from Spanish caves. International Journal of Systematic and Evolutionary Microbiology, 62: 27782785. doi: 10.1099/ijs.0.041004-0

O’DonNELL, K. (1993): Fusarium and its near relatives. In: D. R. Reynolds \& J. W. Taylor (eds.): The Fungal Holomorph: Mitotic, Meiotic and Pleomorphic Speciation in Fungal Systematics. Wallingford: CABI Publishing. pp. 225-233.

RAPER, K. B, THOM, C. (1949): A manual of the penicillia. The Williams \& Wilkins Company, Baltimore, $878 \mathrm{p}$.

RiCKLEFS, R. E. (2004). A comprehensive framework for global patterns in biodiversity. Ecology Letters, 7: 1-15.

Samson, R. A., Visagie, C., Houbraken, J., Hong, S. -B., Hubka, V., Klaassen, C. H. W., Perrone, G., Seifert, K. A., Susca, A., Tanney, J. B., Varga, J., Kocsube, S., Szigeti, G., YAGUCHI, T. and FRISVAD, J. C. (2014): Phylogeny, identification and nomenclature of the genus Aspergillus. Studies in Mycology, 78: 141-173. https://doi.org/10.1016/j.simyco.2014.07.004

Samson, R. A., Houbraken, J., Thrane, U., Frisvad, J. C. and Andersen, B. (2010): Food and Indoor Fungi. [CBS Laboratory Manual series no. 2.], Utrecht: CBS-KNAW Fungal Biodiversity Centre, $390 \mathrm{p}$.

Travadon, R., Lawrence, D. P., Rooney-latham, S., Gubler, W. D., Wilcox, W. F., Rolshausen, P. E. and BAumgartner, K. (2015): Cadophora species associated with wooddecay of grapevine in North America. Fungal Biology, 119(1):53-66. http://dx.doi.org/10.1016/ j.funbio.2014.11.002 
Walsh, E., Duan, W., Mehdi, M., Naphri, K., Khiste, S., Scalera, A. and Zhang, N. (2018): Cadophora meredithiae and C. interclivum, new species from roots of sedge and spruce in a western Canada subalpine forest. Mycologia, 110(1): 201-214. doi: 10.1080/00275514.2017. 1406748

White, T. J, Bruns, T., Lee, S. and TAYlor, J. (1990): Amplification and direct sequencing of fungal ribosomal RNA genes for phylogenetics. In: M. Innis, D. Gelfand, J. Sninsky, T. White (eds.): PCR Protocols: A Guide to Methods and Applications, Academic Press, San Diego, California, pp. 315-322.

Wirtz, N., Printzen, C. and Lumbsch, H. T. (2008): The delimitation of Antarctic and bipolar species of neuropogonoid Usnea (Ascomycota, Lecanorales): A cohesion approach of species recognition for the Usnea perpusilla complex. Mycological Research, 112(4): 472-484. doi: 10.1016/j.mycres.2007.05.006

\section{Web sources / Other sources}

[1] database Index Fungorum www.indexfungorum.org/Names/fungic.asp

[2] GenBank database (NCBI) by using BLAST instrument http://blast.ncbi.nlm.nih.gov/Blast.cgi 